\title{
POLARIZED ABSORPTION SPECTRA OF SELLAITE FROM THE BRUMADO MINE, BRAZIL, IN THE NEAR INFRARED
}

\author{
ANTON BERAN and JOSEF ZEMANN
}

\begin{abstract}
BERAN, ANTON and ZEMANN, JOSEF, 1985: Polarized absorption spectra of sellaite from the Brumado mine, Brazil, in the near infrared. Bull. Geol. Soc. Finland 57, Part 1-2, 113-118.

Polarized absorption spectra of sellaite from the Brumado mine, Brazil, were recorded in the region $\bar{v}=1600-4000 \mathrm{~cm}^{-1}(\lambda=6.25-2.50 \mu \mathrm{m})$. Besides weak, non-pleochroic broad bands in the range of the $\mathrm{H}_{2} \mathrm{O}$ bending and stretching vibrations - evidently caused by liquid inclusions - a sharp pleochroic band was observed at $\bar{v}=3615 \mathrm{~cm}^{-1}$. For this band the absorption is much stronger when the electric vector vibrates perpendicular to [001]; it is tentatively interpreted by a minor substitution of fluorine by hydroxyl groups.
\end{abstract}

Key words: sellaite, IR spectrum, $\mathrm{OH}$ substitution for fluorine.

Anton Beran and Josef Zemann: Institut für Mineralogie und Kristallographie, Universität Wien, Dr. Karl Lueger-Ring 1, A-1010 Wien, Austria.

\section{Introduction}

Although the average abundances of both calcium and magnesium in the magmatic rocks of the Earth's crust are in the range of $1-3 \%$ by weight (cf. e.g. Wedepohl 1969), fluorite, $\mathrm{CaF}_{2} \mathrm{c}$, is a fairly common mineral, whereas sellaite, $\mathrm{MgF}_{2} \mathrm{t}$, is rather rare. For a number of earth scientists the difference in the solubilities in water at room temperature: $\mathrm{CaF}_{2} \sim 16 \mathrm{mg} / \mathrm{l}$, $\mathrm{MgF}_{2} \sim 76 \mathrm{mg} / 1$ (cf. »Handbook of Chemistry and Physics» 1979) does not seem to be sufficient reason for the large difference in the abundances of the two minerals in nature, and Sahama (1945) devoted an interesting publication to this problem.

Since then, several new occurrences of sellaite have been discovered in various geological envi- ronments (for compilations with references see Maus et al. 1979 and Cassedanne and Resende 1983). It has been shown to occur in relatively large amounts but in inconspicuous development in some fluorite deposits, e.g. in Grube Clara near Oberwolfach, Black Forest, the German Federal Republic (Maus 1977, Maus et al. 1979), and in Fontsante mine, Massif du Tanneron, Departement Var, France (Bordet et al. 1964, Solety 1965, Remy et*al. 1974, Wilson 1977). All this has, however, not essentially changed the ratio of the abundances of the two minerals.

Excellent crystals of sellaite, some of gem quality, were recently found in the magnesite deposit of the Brumado mine, Bahia, Brazil (Cassedanne and Resende 1983). In connection with earlier work on hydroxyl groups in the iso- 


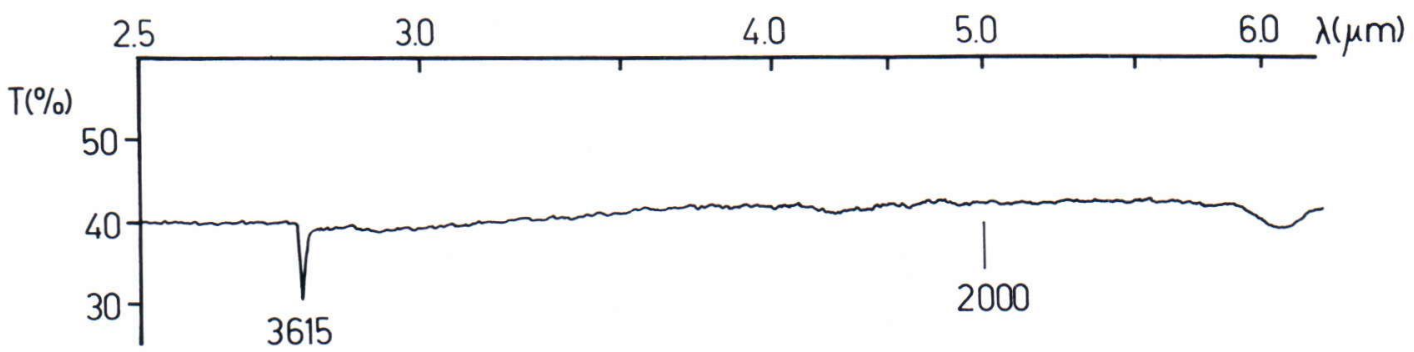

$T(\%)$

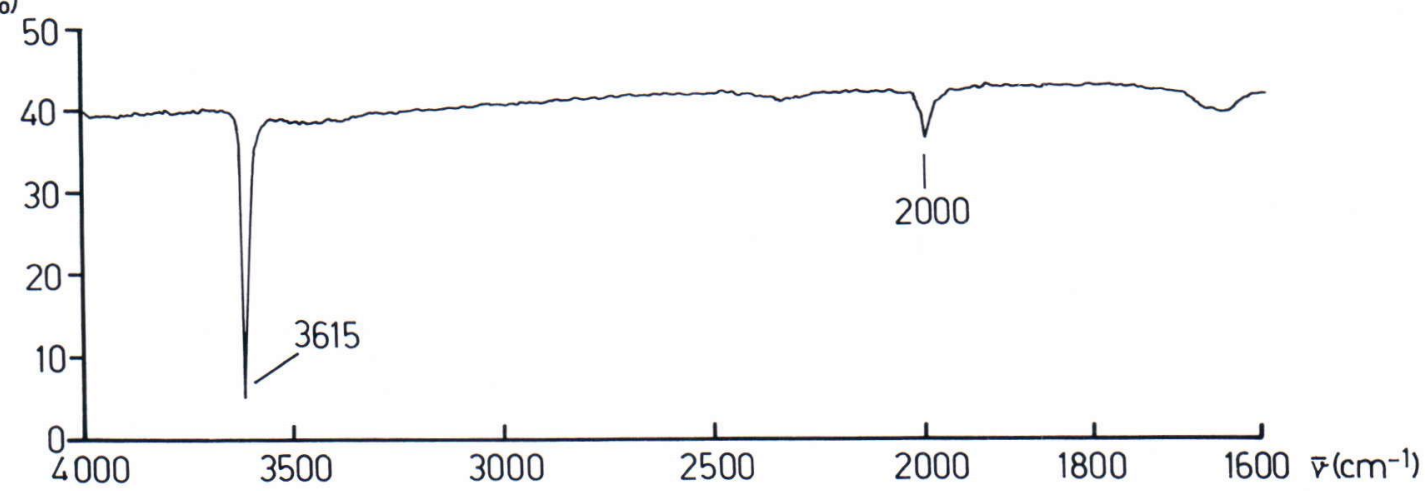

Fig. 1. Sellaite from the Brumado mine. Polarized IR absorption spectra of an (110) plate. Above: electric vector vibrating parallel [001]; below: electric vector vibrating perpendicular to [001]. T: transmission.

typic oxide minerals rutile, $\mathrm{TiO}_{2} \mathrm{t}$, and cassiterite, $\mathrm{SnO}_{2} \mathrm{t}$, by IR spectroscopy (Beran and Zemann 1971), we decided to investigate sellaite from this locality for a possible $\mathrm{OH}$ content and thus to contribute to knowledge of this interesting mineral.

\section{Experimental}

Microscopic inspection and preliminary IR work showed that the loose crystal chips of sellaite from the Brumado mine, kindly put at our disposal by Professor Cassedanne, contained irregular fluid inclusions up to $0.1 \mathrm{~mm}$ in size. As no chemical analyses from this material seem to exist, we checked it for possible iron content by electron microprobe analysis; the result was $\leq 0.05 \% \mathrm{Fe}$ by weight. By the same method a calcium content of $\leq 0.01 \%$ was obtained. Hydrogen determination by standard organic microchemical methods gave $\sim 0.01 \% \mathrm{H}$ by weight for hand-picked material that was apparently free from inclusions.

The optical investigation was conducted in the region $\bar{v}=1600-4000 \mathrm{~cm}^{-1} \lambda=6.25-2.50$ $\mu \mathrm{m})$ with a computer-controlled Perkin Elmer 580 B IR spectrophotometer, Interdata $6 / 16$, equipped with a beam condensor $8 \times$ and a polarizer. The final measurements were done on a plate parallel to the $\{110\}$ cleavage; the orientation was checked by X-ray precession photographs. The diameter of the circular measuring area was $2 \mathrm{~mm}$. Great care was taken to use regions very poor in inclusions for the measurements.

Contrary to synthetic $\mathrm{MgF}_{2}$ crystals supplied by Fa. Leitz (Wetzlar), Fa. Merck (Darmstadt) and AOL-Dr. Schuster (Vienna), thin plates of sellaite from the Brumado mine showed, in the investigated region of the spectrum, four absorption bands: two broad non-pleochroic 
bands at $\overline{\mathrm{v}}=1640 \mathrm{~cm}^{-1}$ and $3450 \mathrm{~cm}^{-1}$ (the last one extremely flat and broad), and two sharp pleochroic bands at $\overline{\mathrm{v}}=3615 \mathrm{~cm}^{-1}$ (relatively strong) ${ }^{1}$ and at $\overline{\mathrm{v}}=2000 \mathrm{~cm}^{-1}$ (weak). For both pleochroic bands the absorption is stronger when the electric vector vibrates perpendicular to [001], i.e. for the ordinary ray (Fig. 1).

To characterize the pleochroic behaviour better, polarized spectra were taken after repeated rotation of the polarizer by $10^{\circ}$. Figure 2 gives the extinction figures on (110) thus obtained.

The non-pleochroic bands completely disappeared after heating the plates to $400^{\circ} \mathrm{C}$ for four days; no other change was observed, and the material remained clear. The same applied to further heating at $500^{\circ} \mathrm{C}$ for the same period. Subsequent heating to $700^{\circ} \mathrm{C}$ for three days caused a reduction in the intensity of the band at $\bar{v}=3615 \mathrm{~cm}^{-1}$ by approximately one quarter and the appearance of a new non-pleochroic band at $\bar{v}=3720 \mathrm{~cm}^{-1}$. Finally, further heating to $1000^{\circ} \mathrm{C}$, again for the same period, caused all the bands to disappear.

\section{Discussion}

Easiest to interpret are the two non-pleochroic absorption bands mentioned above. Their wavelengths, shapes and response to heating indicate strongly that they correspond to the stretching and bending vibrations of $\mathrm{H}_{2} \mathrm{O}$ molecules (for the interpretation of the absorption bands, $c f$. e.g. Nakamoto 1978 , with many references) of the sparing liquid inclusions and possibly also from traces of water on subgrain boundaries ${ }^{2}$.

1 A powder IR absorption spectrum of $» \mathrm{MgF}_{2} \cdot \mathrm{xH}_{2} \mathrm{O}$ » published by Nyquist and Kagel (1971) shows a rather sharp band at this wavelength as well as strong broad water bands.

2 The IR spectra of thick plates show further a weak but sharp non-pleochroic absorption band at $\bar{v}=2340 \mathrm{~cm}^{-1}$, probably attributable to the asymmetric $\mathrm{CO}_{2}$ stretching vibration, and further three extremely weak but sharp bands at $\bar{v}=2850,2920$ and $2960 \mathrm{~cm}^{-1}$, possibly caused by $\mathrm{CH}$ stretching vibrations. There seems to be little doubt that all these weak bands are connected with fluid inclusions.

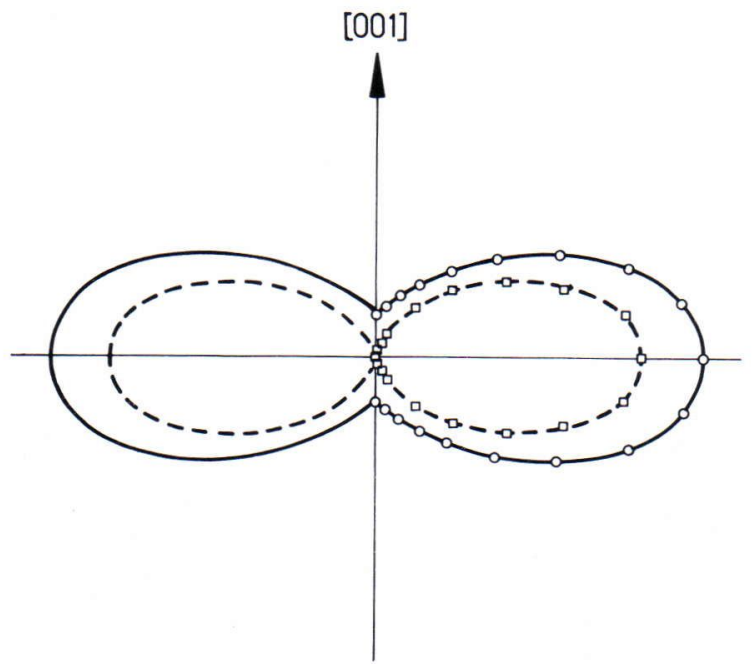

Fig. 2. Sellaite from the Brumado mine. Extinction figures on (110). Plotted are relative values of the extinction, $\mathrm{E}=$ $\log \left(I_{0} / \mathrm{I}\right)$. Full line: $\bar{v}=3615 \mathrm{~cm}^{-1}$; broken line: $\bar{v}=2000$ $\mathrm{cm}^{-1}$. Note that the scale of the $2000 \mathrm{~cm}^{-1}$ band is ten times that of the $3615 \mathrm{~cm}^{-1}$ band.

The wavenumber of the sharp pleochroic band at $\overline{\mathrm{v}}=3615 \mathrm{~cm}^{-1}$ lies in the range characteristic for $\mathrm{OH}$ stretching vibrations with practically no hydrogen bridging; it compares well with that in brucite, $\operatorname{Mg}(\mathrm{OH})_{2} \mathrm{~h}$, with $\overline{\mathrm{v}}=3698$ $\mathrm{cm}^{-1}$ (Ryskin 1974). The extinction figure indicates an orientation of the dipoles parallel to (001) or approximately so. A reasonable interpretation is to assume minor replacement of fluorine by hydroxyl groups in the atomic arrangement ${ }^{3}$. The amount of this replacement can be estimated only very approximately. If the total analytical $\mathrm{H}$ content of $\sim 0.01 \%$ by weight (= ca. $0.09 \%$ by weight equivalent $\mathrm{H}_{2} \mathrm{O}$ ) were to stem from hydroxyl groups, one in $300 \pm 100 \mathrm{~F}^{-}$ions would be replaced by

3 In this context it should be mentioned that on the basis of secondary ion mass spectroscopy, Buhl and Preisinger (1979) reported the occurrence of $\mathrm{OH}$ ions on and near the surface of artificial $\mathrm{MgF}_{2}$ crystals. In our sellaite the bulk of the carriers of the absorption band with $\bar{v}=3615 \mathrm{~cm}^{-1}$ is definitely not located at the surface of the plates because the intensity decreases with decreasing thickness of the plates. 
$\mathrm{OH}^{-}$. It should, however, be borne in mind that the material analysed also contained traces of liquid inclusions. From the IR spectrum we estimate that $10-30 \%$ of the hydrogen content is in the liquid inclusions. A replacement of one $\mathrm{OH}$ group per five hundred $\mathrm{F}^{-}$ions seems, therefore, to give the correct order of magnitude. This estimation is also in fair accordance with our internal calibration of $\mathrm{OH}$ contents from the intensity of the absorption band of the $\mathrm{OH}$ stretching vibration (Beran et al. 1981) which gives $\sim 0.13 \%$ by weight analytical $\mathrm{H}_{2} \mathrm{O}$ for our analysed material.

In the crystal structure of sellaite (recent refinements including thermal vibrations and their discussion, and electron density: Baur 1976, Vidal-Valat et al. 1979, Pauling 1980, VidalValat et al. 1980, Vidal et al. 1981) the fluorine ions are strictly planarly surrounded by three

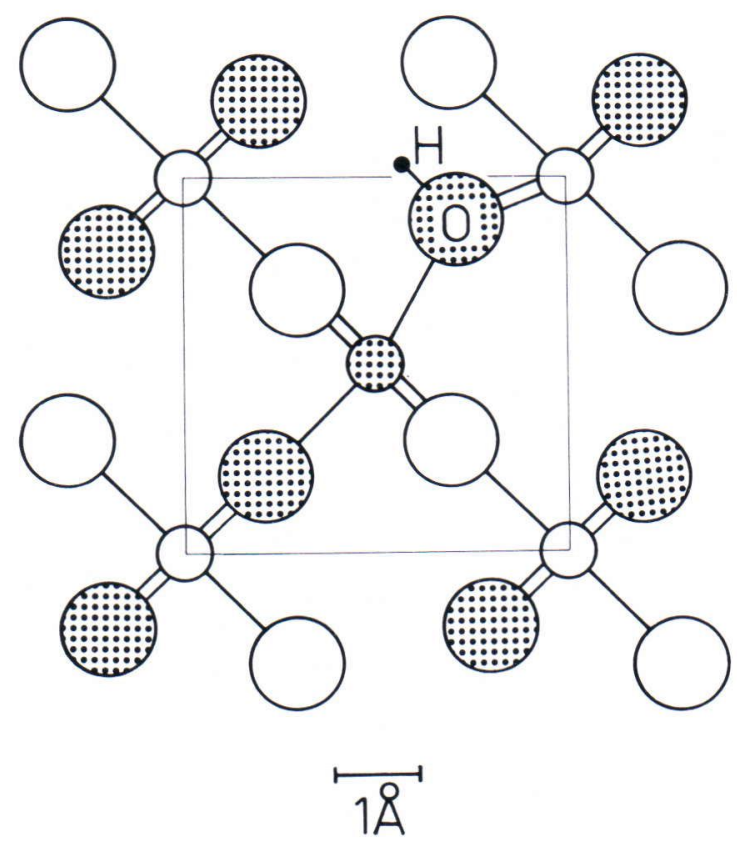

Fig. 3. Sellaite. Projection of the structure parallel to [001]. One of the fluorine ions is replaced by an hydroxyl group, and the expected local distortion of the atomic arrangement is schematically indicated. Small circles: $\mathrm{Mg}^{2+}$, large circles: $\mathrm{F}^{-}$(if not labelled as $\mathrm{O}$ ). Blank circles: $\mathrm{z}=0$, dotted circles: $\mathrm{z}=\mathrm{c} / 2$. magnesium ions at almost equal distances. The planes of each three of these magnesium ions always lie exactly parallel to (110) or to the crystallographically equivalent plane (110). As a consequence, substitution of $\mathrm{F}^{-}$by $\mathrm{OH}^{-}$will cause the $\mathrm{OH}$ dipoles to lie parallel to (001). From general experience in solid state chemistry it is to be expected that this causes local distortion of the atomic arrangement, whereby the oxygens adopt a distorted tetrahedral coordination with respect to the $\mathrm{H}$ atom of the hydroxyl group and to three $\mathrm{Mg}^{2+}$ ions (Fig. 3).

Unfortunately, hydrothermal treatment with heavy water at temperatures up to $400^{\circ} \mathrm{C}$ did not cause the appearance of an absorption band at $\overline{\mathrm{v}} \sim 2700 \mathrm{~cm}^{-1}$ as would be expected if $\mathrm{H}$ were partly replaced by $\mathrm{D}$ in the hydroxyl groups. This is at variance with the behaviour of natural rutile and cassiterite (Beran and Zemann 1971; for $\mathrm{OH}$ in artificial rutile see von Hippel et al. 1961). The attribution of the absorption band at $\bar{v}=3615 \mathrm{~cm}^{-1}$ is, therefore, only tentative at present and needs confirmation by IR work on OD-doped artificial sellaite crystals. Further, the band under discussion here has a somewhat weaker pleochroism than the (proven) $\mathrm{OH}$ band in rutile. This can possibly be explained by the weaker $\mathrm{Mg}-\mathrm{O}$ bonds as compared with the $\mathrm{Ti}-\mathrm{O}$ bonds.

For their sellaite from Grube Clara, Maus et al. (1979) reported an analytical water content of $\sim 3.0 \%$ by weight, of which $90 \%$ could be driven out in the heating interval from $600^{\circ}$ to $800^{\circ} \mathrm{C}$. For this part of the $\mathrm{H}_{2} \mathrm{O}$, Maus et al. (l.c.) postulated »gebundenes Wasser» (bound water). They report that this result was confirmed by an IR analysis clearly proving the presence of hydroxyl $(\mathrm{OH})$ groups. To check this result, we also took IR absorption spectra of the sellaite from Grube Clara kindly provided by Dr. Maus. Microscopic inspection had shown that the material was very rich in tiny fluid inclusions, and the absorption spectra showed two broad strong bands in the region of the bending and stretching vibrations of liquid 
water. No sharp $\mathrm{OH}$ band was detected.

The weak absorption band at $\overline{\mathrm{v}}=2000$ $\mathrm{cm}^{-1}$ for sellaite from the Brumado mine shows an even stronger pleochroism than that at $\overline{\mathrm{v}}=3615 \mathrm{~cm}^{-1}$ (Fig. 2). A convincing interpretation is not possible at present. The wavelength would be compatible with a very short hydrogen bridge, but the line width is small for such an inference.

In summary we can say that besides absorption bands from liquid inclusions and possibly also from water on subgrain boundaries, a sharp pleochroic band at $\bar{v}=3615 \mathrm{~cm}^{-1}$ was detected in the sellaite from the Brumado mine. It is tentatively attributed to the $\mathrm{OH}$ stretching

\section{References}

Baur W. H., 1976. Rutile-type compounds. V. Refinement of $\mathrm{MnO}_{2}$ and $\mathrm{MgF}_{2}$. Acta Cryst. B32, 2200-2204.

Beran A.; Götzinger M. \& Zemann J., 1981. Infrarotspektroskopische Untersuchungen über den $\mathrm{OH}-$ Gehalt von Pyroxenen und Cyaniten aus Gesteinen. Fortschr. Miner. 59, Beih. 1, 16-18.

Beran A. \& Zemann J., 1971. Messung des Ultrarot-Pleochroismus von Mineralen. XI. Der Pleochroismus der $\mathrm{OH}-$ Streckfrequenz in Rutil, Anatas, Brookit und Cassiterit. Tschermaks Min. Petr. Mitt. 15, 71-80.

Bordet P.; Charrier J. \& Geffroy J., 1964. La sellaite du gisement de fluorine de Font-Sante (Var). Bull. Soc. franç. Minér. Crist. 87, 451-452.

Buhl R. \& Preisinger A., 1979. Studies of dynamic effects at non-metal surfaces with incident low energy electrons. Vacuum 30, 209-211.

Cassedanne J. P. \& Resende J. P., 1983. Sellaite from the Brumado mine. Mineral. Record 14, 179-181.

»Handbook of Chemistry and Physics» 59th Ed. (R. C. Weast, Ed.) CRC Press Inc., West Palm Beach, Florida.

Hippel A. von; Kalnajs J. \& Westphal W. B., 1962. Protons, dipoles, and charge carriers in rutile. J. Phys. Chem. Solids 23, 779-799.

Maus H., 1977. Violetter Fluorit und Sellait von der Grube Clara, Oberwolfach, Schwarzwald. Aufschluß 28, 361367.

Maus H.; Gundlach H. \& Podufal P., 1979. Über den Sellait $\left(\mathrm{MgF}_{2}\right)$ der Grube Clara, Oberwolfach, Mittlerer Schwarzwald. N. Jb. Miner. Abh. 136, 10-25. vibration of a minor substitution of fluorine by hydroxyl groups in this mineral. The final proof will probably need work on OD -doped artificial crystals. Further experimental studies are also needed for a convincing inference of a weak pleochroic band at $\overline{\mathrm{v}}=2000 \mathrm{~cm}^{-1}$.

Acknowledgements. Our hearty thanks are due to Professor J. Cassedanne, Brazil, and to Dr. H. Maus, German Federal Republic, for sellaite samples. The IR investigation was made possible by the support of the $»$ Fonds zur Förderung der Wissenschaftlichen Forschung», Austria (Project No. 3735). Dr. G. Kurat kindly permitted us to use the electronmicroprobe equipment of the »Naturhistorisches Museum» Vienna, and Professor W. D. Johns, University of Missouri, revised the manuscript.

Nakamoto K., 1978. Infrared and Raman Spectra of Inorganic and Coordination Compounds. John Wiley \& Sons, New York - Chichester - Brisbane - Toronto.

Nyquist R. A. \& Kagel R. O., 1971. Infrared Spectra of Inorganic Compounds. Academic Press, New York San Francisco - London.

Pauling L., 1980. Atomic vibrations in the magnesium difluoride crystal. Acta Cryst. B36, 761-762.

Remy F.; Thibon Au.; Lescure J. \& Feraud J., 1974. Sur l'exploitation de la fluorine dans le champ filonien de Fontsante (Massif du Tanneron, Var). Bull. du B.R.G.M. (deuxième série) Section II, 477-488.

Ryskin Ya.I., 1974. The vibrations of protons in minerals: hydroxyl, water and ammonium. In: The Infrared Spectra of Minerals (Farmer V. C., Ed.) Miner. Soc. Monograph 4. Mineral Society: London. 137-181.

Sahama Th. G., 1945. Abundance relation of fluorite and sellaite in rocks. Ann. Acad. Sci. Fennicae, Ser. A, III. Geol. Geogr. 9, 21 pp.

Solety P., 1965. Les gisements du fluorite de la Provence Cristalline (Maures, Tanneron, Esterél). Mémoirs B.R.G.M. No. 39.

Vidal J.-P.; Vidal-Valat G.; Galtier M. \& Kurki-Suonio K., 1981. X-ray study of the charge distribution in $\mathrm{MgF}_{2}$. Acta Cryst. A37, 826-837.

Vidal-Valat G.; Vidal J.-P.; Zeyen C. M. E. \& KurkiSuonio K., 1979. Neutron diffraction study of magnesium fluoride single crystals. Acta Cryst. B35, 1584-1590.

Vidal-Valat G.; Vidal J.-P.; Zeyen C. M. E. \& Kurki-Suonio $K ., 1980$. On the atomic vibrations in the magnesium 
difluoride crystal. Acta Cryst. B36, 2857.

Wedepohl K. H., 1969. Composition and abundance of common igneous rocks. In: Handbook of Geochemistry. I. (Wedepohl K. H., Ed.) Springer-Verlag, Berlin-
Heidelberg - New York. 227-249.

Wilson F. A., 1977. Fluorite from the Font Sante Mine, Esteral, Var, France. Mineral. Record 8, 308-311. 